\title{
Cytogenetic Pattern in Adult Patients with de novo Acute Myeloid Leukaemia: A Single Centre Study in Bangladesh
}

\author{
Saqi Md. Abdul Baqi1 ${ }^{*}$, Umme Kulsum Munmun², Shafiqul Islam³, Farzana Rahman³, Md. Rafiquzzaman Khan², \\ Md. Salahuddin Shah ${ }^{3}$, Md. Abdul Aziz ${ }^{3}$, Masuda Begum ${ }^{3}$ \\ ${ }^{1}$ Department of Haematology and BMT, Dhaka Medical College Hospital, Dhaka, Bangladesh. \\ ${ }^{2}$ Department of Pathology, Dhaka Medical College, Dhaka, Bangladesh. \\ ${ }^{3}$ Department of Haematology, Bangabandhu Sheikh Mujib Medical University, Shahbag, Dhaka, Bangladesh.
}

\begin{abstract}
Citation: Baqi SMA, Munmun UK, Islam S, Rahman F, Khan MR, Shah MS, Aziz MA, Begum M. Cytogenetic Pattern in Adult Patients with de novo Acute Myeloid Leukaemia: A Single Centre Study in Bangladesh. Haematol J Bangladesh 2020; 4 (1): 08-12.
\end{abstract}

DOI: http://doi.org/10.37545/haematoljbd 202047

Received: 09 April 2020

Accepted: 16 April 2020

Published: 20 June 2020

*Correspondence: Saqi Md. Abdul Baqi, Medical Officer, Department of Haematology and BMT, Dhaka Medical College Hospital, Dhaka. saqi.dmc@ gmail.com, Contact: +8801712588002.
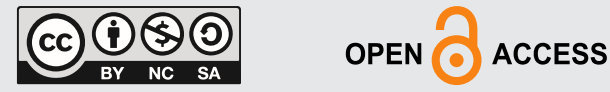

Copyright: (C) 2020 by author(s). This is an open access article published under the Creative Commons Attribution-Non Commercial-No Derivatives 4.0 International License, which permits use, distribution and reproduction in any medium or format, provided the original work is properly cited, is not changed in any way and is not used for commercial purposes. http:// creativecommons.org/licenses /by/4.0/

Funding: This study was carried out with the support of Research Grant of Bangabandhu Sheikh Mujib Medical University (BSMMU).

in the peripheral blood or bone marrow. However, in a subgroup of AML, the presence of recurrent genetic abnormalities alone is sufficient for the diagnosis of AML regardless of the blast percentage. ${ }^{7}$ Geographical,

\begin{abstract}
Background: Cytogenetic analysis performed at diagnosis is the most important prognostic factor in AML. Objective: The purpose of this study was to observe the pattern of cytogenetic abnormalities in adult patients with de novo AML. Method: Total fifty-two newly diagnosed de novo AML patients were selected for the study. Six cytogenetic abnormalities including t(8;21), t(15;17), inv(16), BCR-ABL1, FLT3-ITD and NPM1 mutations were studied by Real-Time PCR. Results: In this study, 36 (69.2\%) patients showed different cytogenetic abnormalities. The $t(15 ; 17)$ was found to be the most common. $t(15 ; 17)$, $t(8 ; 21)$ and inv(16) were found only in M3, M2 and M4 FAB subtypes, respectively. Conclusion: Cytogenetic study should be performed routinely in all cases of AML for proper diagnosis, prediction of prognosis and implementation of effective therapeutic measures.
\end{abstract}

Key words: acute myeloid leukaemia, cytogenetics.

\section{Introduction}

Acute myeloid leukaemia (AML) is a clonal, malignant disease of haematopoietic tissue which is characterized by accumulation of abnormal (leukaemic) blast cells, principally in the bone marrow, and impaired production of normal blood cells. ${ }^{1}$ The incidence of AML is higher in the white population (3.8 per 100,000 person) than that of the Asian population (3.2 per 100,000 person). ${ }^{2}$ AML is the most common acute leukaemia in adult and it is more common in males. Majority of the AML patients are older than 60 years. ${ }^{3}$ Cytogenetic abnormalities were first described in AML in the 1960s. ${ }^{4}$ In 1988, the Morphologic, Immunologic and Cytogenetic (MIC) classification was published. Since then, cytogenetic investigations have become more important in AML classification. ${ }^{5}$ AML is heterogeneous in terms of morphology, immunophenotype, cytogenetics and molecular genetics. ${ }^{6}$ Using the World Health Organization (WHO) criteria, the diagnosis of AML is established by the presence of $20 \%$ or more of leukaemic myeloblasts ethnic, and environmental influences should be considered in determining the cytogenetic and morphological features of this disease. ${ }^{8}$ Cytogenetic abnormalities are identified in $50-60 \%$ of adult newly diagnosed AML 
patients. ${ }^{9}$ Age and cytogenetic abnormalities are the most important prognostic factors in AML. ${ }^{10}$ There is an increase in the proportion of patients with unfavourable risk cytogenetics and a decrease in favourable risk cytogenetics with advancing age. ${ }^{11}$ Besides the prognostic importance, cytogenetic analysis is also recommended to monitor minimal residual disease (MRD) in case of AML patients with abnormal cytogenetics. ${ }^{12}$

From these points of view, the current study was designed to observe the pattern of cytogenetic abnormalities in adult patients with de novo AML, to categorize the patients into three risk groups and to observe the association of cytogenetic findings with FAB subtypes, age, sex and other laboratory findings.

\section{Methods}

This observational study was conducted in the department of Haematology, Bangabandhu Sheikh Mujib Medical University (BSMMU), from February 2018 to January 2019. Total fifty-two newly diagnosed adult patients with de novo AML had been enrolled for the study by purposive type of sampling technique. Patients with myelodysplastic syndrome and chronic myeloid leukaemia transforming into AML and therapy-related AML were excluded from the study. Informed consent was taken from the subjects. Ethical clearance was obtained from institutional review board (IRB) of BSMMU. Complete blood count was done by automated cell counter machine and checked manually. Morphological diagnosis of AML had been done by bone marrow study. For cytogenetic study, 3-5 ml of peripheral blood or bone marrow aspirate was collected in EDTA tube and was sent to the laboratory as early as possible with appropriate precautions. Cytogenetic investigations were done on Dr Lal Path Labs Ltd. India. Six cytogenetic abnormalities including $\mathrm{t}(8 ; 21), \mathrm{t}(15 ; 17)$, inv(16), BCR-ABL1, FLT3-ITD and NPM1 mutations were detected by Real-Time Polymerase Chain Reaction (RT PCR) technique. The ABI 7500 RT PCR system (using the Taqman chemistry) was used for doing the cytogenetic analysis. The ABI 7500 RT PCR Instrument with SDS Software is a real-time nucleic acid amplification and five-color fluorescence detection system used for in vitro diagnostic. At the start of RT PCR, the temperature is raised to denature the double-stranded DNA. In the next step, the reaction temperature is lowered to allow the primers and probe to anneal to their specific target sequences. Taq DNA polymerase synthesizes new strands using the unlabeled primers and the template. When the polymerase reaches a TaqMan probe, its endogenous 5' nuclease activity cleaves the probe, separating the fluorescence dye from the quencher which is then measured by a CCD camera at each cycle of amplification.

A pre-designed semi-structured data collection sheet was used for data collection. The statistical analysis was carried out using the Statistical Package for Social Sciences version 24.0 for Windows (SPSS Inc., Chicago, Illinois, USA). Qualitative variables of this study were expressed as percentage. Quantitative variables were expressed as mean \pm standard deviation. Chi-Square test was used for categorical variables. To compare means of two groups' unpaired t-test was used in case of normally distributed data and Mann-Whitney $U$ test was used where the data were not normally distributed. For all statistical tests, p-value less than 0.05 was considered as statistically significant.

\section{Results}

The mean age of the patients was $37( \pm 13.29)$ years. Maximum (30.8\%) patients belonged to $18-27$ years age group. Female was slightly predominant with a male: female ratio was 1: 1.08. Maximum patients belonged to FAB M2 (32.7\%), followed by M3 (26.9\%) and M1 (17.3\%). Among the 52 cases, 36 (69.2\%) cases showed different cytogenetic abnormalities and 16 (30.8\%) cases had normal cytogenetics. The $\mathrm{t}(15 ; 17)$ was found to be the most common, detected in 13 (25\%) patients. NPM1 mutation was found in $10(19.23 \%), \mathrm{t}(8 ; 21)$ in 8 $(15.38 \%)$ and FLT3-ITD mutation in 8 (15.38\%) cases (Table I).

Table I: Cytogenetic pattern in study subjects. (n:52)

\begin{tabular}{lc}
\hline Cytogenetic pattern & $\mathbf{n}(\%)$ \\
\hline Normal cytogenetics & $16(30.8)$ \\
$\mathrm{t}(8 ; 21)$ & $7(13.5)$ \\
$\mathrm{t}(15 ; 17)$ & $12(23.1)$ \\
inv(16) & $2(3.8)$ \\
BCR-ABL1 & $1(1.9)$ \\
NPM1 & $6(11.5)$ \\
FLT3-ITD & $2(3.8)$ \\
NPM1 and FLT3-ITD & $4(7.7)$ \\
$\mathrm{t}(8 ; 21)$ and FLT3-ITD & $1(1.9)$ \\
$\mathrm{t}(15 ; 17)$ and FLT3-ITD & $1(1.9)$ \\
Total & $\mathbf{5 2 ( 1 0 0 )}$ \\
\hline
\end{tabular}

M0 and M6 subtypes did not show any cytogenetic abnormality. Most of the M1 cases also had normal cytogenetic pattern. The $t(15 ; 17), t(8 ; 21)$ and inv(16) were found only in M3, M2 and M4 FAB subtypes respectively. Only one case showed BCR-ABL1 mutation which belongs to M1 subtype. A combination of NPM1 
and FLT3-ITD mutation was found in M4, M1, M3 and M2 subtypes (Table II).

Table II: Distribution of specific cytogenetics among FAB subtypes of AML. (n:52)

\begin{tabular}{|c|c|c|c|c|c|c|c|}
\hline \multirow[t]{2}{*}{ Cytogenetic pattern } & \multicolumn{7}{|c|}{ FAB subtypes; n (\%) } \\
\hline & M0 & M1 & M2 & M3 & M4 & M5 & M6 \\
\hline $\mathrm{t}(8 ; 21)$ & & & $7(13.5)$ & & & & \\
\hline $\mathrm{t}(15 ; 17)$ & & & & $12(23.1)$ & & & \\
\hline $\operatorname{inv}(16)$ & & & & & $2(3.8)$ & & \\
\hline BCR-ABL1 & & $1(1.9)$ & & & & & \\
\hline NPM1 & & $1(1.9)$ & $2(3.8)$ & & $2(3.8)$ & $1(1.9)$ & \\
\hline FLT3-ITD & & & & & $2(3.8)$ & & \\
\hline NPM1 and FLT3-ITD & & $1(1.9)$ & $1(1.9)$ & $1(1.9)$ & $1(1.9)$ & & \\
\hline $\mathrm{t}(8 ; 21)$ and FLT3-ITD & & & $1(1.9)$ & & & & \\
\hline $\mathrm{t}(15 ; 17)$ and FLT3-ITI & & & & $1(1.9)$ & & & \\
\hline Normal cytogenetics & $2(3.8)$ & $6(11.5)$ & $6(11.5)$ & & & $1(1.9)$ & $1(1.9)$ \\
\hline Total & $2(3.8)$ & $9(17.3)$ & 17 (32.7) & 14 & 7 (13.5) & $2(3.8)$ & $1(1.9)$ \\
\hline
\end{tabular}

No significant difference observed between abe among different cytogenatic pattern. In only one case with 78 years of AML M1 had BCR-ABL1 mutation. (Table III).

Table III: Relationship of cytogenetic abnormalities with age (years). (n:52)

\begin{tabular}{lccccc}
\hline $\begin{array}{l}\text { Cytogenetic } \\
\text { pattern }\end{array}$ & $\mathbf{n ~ ( \% )}$ & $\begin{array}{c}\text { Present } \\
\text { Mean age } \pm \text { SD }\end{array}$ & $\mathbf{n}(\%)$ & Mean age \pm SD & p- value \\
\hline $\mathrm{t}(8 ; 21)$ & $8(15.4)$ & $30.00 \pm 10.30$ & $44(84.4)$ & $38.11 \pm 13.49$ & 0.107 \\
$\mathrm{t}(15 ; 17)$ & $13(25.0)$ & $31.92 \pm 8.42$ & $39(75.0)$ & $38.51 \pm 14.27$ & 0.150 \\
inv16 & $2(3.8)$ & $40.50 \pm 7.77$ & $50(96.2)$ & $36.72 \pm 13.50$ & - \\
BCR-ABL1 & $1(1.9)$ & 78.00 & $51(98.1)$ & $36.06 \pm 12.07$ & - \\
NPM1 & $10(19.2)$ & $42.80 \pm 11.76$ & $42(80.8)$ & $35.45 \pm 13.37$ & 0.073 \\
FLT3-ITD & $8(15.4)$ & $35.13 \pm 13.52$ & $44(84.6)$ & $37.18 \pm 13.39$ & 0.713 \\
\hline
\end{tabular}

Favourable cytogenetics were more frequent in younger age groups. Intermediate and unfavourable cytogenetics were common in relatively older age groups. These findings were statistically significant (p:0.004) (Table IV).

Table IV: Distribution of the cases according to different age groups and cytogenetic risk groups. (n:52)

\begin{tabular}{|c|c|c|c|c|}
\hline \multirow{2}{*}{ Age groups (years) } & \multicolumn{3}{|c|}{ Cytogenetic risk groups; n (\%) } & \multirow{2}{*}{ p-value } \\
\hline & Favorable & Intermediate & Unfavorable & \\
\hline $18-27$ & $9(56.3)$ & $6(37.5)$ & $1(6.3)$ & \\
\hline$>27-37$ & $8(57.1)$ & $5(35.7)$ & $1(7.1)$ & \\
\hline$>37-47$ & $7(70.0)$ & $3(30.0)$ & $0(0.0)$ & 0.004 \\
\hline$>47-57$ & $3(27.3)$ & $8(72.7)$ & $0(0.0)$ & \\
\hline$>57$ & $0(0.0)$ & $0(0.0)$ & $1(100)$ & \\
\hline
\end{tabular}

FLT3-ITD mutation was significantly associated with increased WBC count (p: 0.042) (Table V).
Table V: Relationship of cytogenetic abnormalities with WBC count (x109/L). (n:52)

\begin{tabular}{lccccc}
\hline & \multicolumn{5}{c}{ WBC count $(\mathbf{x 1 0} / \mathbf{L})$} \\
$\begin{array}{l}\text { Cytogenetic } \\
\text { pattern }\end{array}$ & $\mathbf{n}(\%)$ & Meant \pm SD & $\mathbf{n}(\%)$ & Mean \pm SD & p value \\
\hline $\mathrm{t}(8 ; 21)$ & $8(15.4)$ & $45.71 \pm 86.99$ & $44(84.4)$ & $26.12 \pm 32.98$ & 0.603 \\
$\mathrm{t}(15 ; 17)$ & $13(25.0)$ & $26.33 \pm 39.69$ & $39(75.0)$ & $30.07 \pm 46.82$ & 0.492 \\
inv16 & $2(3.8)$ & $7.55 \pm 8.55$ & $50(96.2)$ & $30.00 \pm 45.47$ & - \\
BCR-ABL1 & $1(1.9)$ & 8.50 & $51(98.1)$ & $29.54 \pm 45.14$ & - \\
NPM1 & $10(19.2)$ & $30.90 \pm 40.19$ & $42(80.8)$ & $28.72 \pm 46.26$ & 0.546 \\
FLT3-ITD & $8(15.4)$ & $44.93 \pm 41.17$ & $44(84.6)$ & $26.26 \pm 45.27$ & 0.042 \\
\hline
\end{tabular}

No significant difference observed between bonemarrow blast percentage with different cytogenatic pattern.. (Table VI).

Table VI: Relationship of cytogenetic abnormalities with bone marrow blast (\%). (n:52)

\begin{tabular}{|c|c|c|c|c|c|}
\hline \multirow[b]{2}{*}{$\begin{array}{l}\text { Cytogenetic } \\
\text { pattern }\end{array}$} & \multicolumn{4}{|c|}{ bone marrow blast (\%) } & \multirow[b]{2}{*}{ p value } \\
\hline & (\%) & $\begin{array}{l}\text { Present } \\
\text { Mean } \pm \text { SD }\end{array}$ & $1(10)$ & $\begin{array}{l}\text { Absent } \\
\text { Mean } \pm \text { SD }\end{array}$ & \\
\hline 8.211 & , & . & 4) & 72. & 0.560 \\
\hline$(15$ & 0) & 76 & 3 & 70.7 & 0.675 \\
\hline nv16 & (38) & 4000 & 50 & $73.46=$ & - \\
\hline BCR-A & $1(1.9)$ & 80.00 & 51 & 72.01 & - \\
\hline JPM1 & $10(19.2)$ & $65.30 \pm 24.71$ & $42(80.8)$ & $73.80 \pm 13.96$ & 0.452 \\
\hline FLT3-ITD & $8(15.4)$ & $64.75 \pm 18.02$ & $44(84.6)$ & $73.52 \pm 16.19$ & 0.081 \\
\hline
\end{tabular}

Patients with normal cytogenetics showed significant association with relatively increased bone marrow blast percentage (p:0.033). No other parameter (sex, haemoglobin level, platelet count) showed any significant association with cytogenetic pattern.

\section{Discussion}

AML is characterized by a spectrum of clinical, morphological, immunophenotypic and associated cytogenetic abnormalities. In this study the mean age at presentation of AML was 37 years. Studies in most of the other countries showed much higher mean age.,6,13-15 The reason for this difference may be due to inclusion of only de novo cases of AML in this study or may be geographic/ethnic influence.

Cytogenetic abnormalities were detected in $69.2 \%$ of patients with an increased frequency of $t(15 ; 17)$ in this study. These findings are consistent with the results of several other studies conducted by Ayesh et al. (2012) and Enjeti et al. (2004). ${ }^{13,16}$ Here, favourable cytogenetic risk group belonged to young patients and frequency of unfavourable cytogenetics were higher in older age groups. Similarly, Meng et al. (2013) found 75\% favourable cytogenetics in young patients and mostly complex karyotype in elderly patients. ${ }^{6}$ 
Male: female ratio in this study was 1:1.08. This finding differs from most of the studies in other countries where male predominance was found. ${ }^{6,13,17}$ This difference is probably due to greater proportion of female bed in our department. Geographic or ethnic influence may also be responsible. An increased frequency of $t(15 ; 17)(28 \%)$ was found among the male patients in this study. Enjeti et al. (2004) also found increased frequency of $t(15 ; 17)$ among male patients in a study from Singapore. ${ }^{13}$ No other significant difference was found in this study among male and female patients in relation to cytogenetics.

Cases with FLT3-ITD mutation were found in this study to have increased WBC count. Peng et al. (2008) also demonstrated a correlation between the presence of FLT3 mutation and the increased WBC count. ${ }^{18}$ Similarly, Schnittger et al. (2002) and Haferlach et al. (2012) reported NPM1 and FLT3 mutations to be correlated with higher peripheral WBC count. ${ }^{19,20}$

The $t(15 ; 17)$ was found to be the most common $(25 \%)$ cytogenetic abnormality in this study. The frequency of $t(15 ; 17)$ found in this study is much higher than other parts of Asia, like Taiwan (15\%), compared to those observed in North America and Europe (3-10\%). ${ }^{21,22}$ The $\mathrm{t}(15 ; 17)$ was found in $85.7 \%$ of M3 subtype patients in the current study, which is very close to the findings in Singapore (82.5\% of M3 patients), compared to Japan (75.4\%) and Europe (72.5\%). ${ }^{8,13,22}$

On the other hand, $\mathrm{t}(8 ; 21)$ was found in $41.2 \%$ of AML M2 patients in this study. This percentage is closer to the incidence found in Japanese and Taiwanese reports (33.1\% and 34\% of their AML M2 patients). ${ }^{8,21}$ The $\mathrm{t}(8 ; 21)$ is less frequent among the AML M2 patients in Singapore (14.5\%), Australia (15.3\%) and North America (22\%). ${ }^{13,23,24}$

In this study, significant difference was found in case of inv(16) pattern between M4 and non-M4 subtypes. Enjeti et al. (2004) also found the highest frequency of inv(16) among their M4 cases. ${ }^{13}$

FLT3-ITD mutation was found more frequently in M4 subtype in this study. Similarly, another study carried out by Koczkodaj et al. (2016) in Southeastern Poland found the highest frequency of FLT3-ITD mutation in AML M4 cases. ${ }^{25}$ In an Iranian study, Rezaei et al divided the patients into FAB M3 and non-M3 groups and analysed the FLT3-ITD and NPM1 mutational status among these patients. ${ }^{26}$ They also found that these mutations were more frequent in non-M3 patients. On the other hand, Smith et al. (2011) found a higher frequency of FLT3-ITD mutations among M3 patients. ${ }^{27}$ Falini et al. (2005) observed that FLT3-ITD mutations occur twice as often in the cases with simultaneous NPM1 mutations as in the cases without this mutation. ${ }^{28}$ The current study also shows that co-existent FLT3-ITD and NPM1 mutations are more frequent than FLT3-ITD mutation alone. These differences in the frequency of cytogenetic/molecular genetic abnormalities might be due to geographic and ethnic heterogenicity, variation in the sample size or inclusion of paediatric patients in some studies. Paediatric patients were excluded in our study.

\section{Conclusion}

Significant number of patients showed different cytogenetic abnormalities. Therefore, cytogenetic study should be performed routinely in all cases of AML for proper diagnosis, prediction of prognosis and implementation of effective therapeutic measures.

\section{Limitations}

Samples were collected from only one center and sample size was small; hence it may not represent the whole population of the community. Duration of the study was short. Six cytogenetic abnormalities were analyzed in this study because of resource constraints.

\section{Recommendations}

Cytogenetic study should be performed routinely in all cases of AML for proper diagnosis, prediction of prognosis and implementation of effective therapeutic measures. A cytogenetic and molecular genetic laboratory should be established at Haematology department of BSMMU. Future studies with a larger sample size and more cytogenetic markers are recommended.

\section{References}

1. Liesveld JL, Lichtman MA. Acute myelogenous leukemia. Williams hematology, 9th ed, Kaushansky K, Lichtman MA, Prchal JT, et al (Eds). McGraw-Hill Education; 2015:1373-1436.

2. Howlader N, Noone AM, Krapcho M, Neyman N, et al. SEER Cancer Statistics Review, 1975-2009 (Vintage 2009 Populations), National Cancer Institute, Bethesda, MD, http://seeer. cancer.gov /csr/1975_2009_pops09/, based on November 2011 SEER data submission, posted on SEER web site 2012.

3. Provan D, Baglin T, Dokal I, de Vos J. Oxford Handbook of Clinical Haematology. OUP Oxford; 2015 Apr 23:124-214.

4. Greer JP, Arber DA, Glader B, List AF, Means RT, Paraskevas F, Rodgers GM. Wintrobe's clinical hematology. Lippincott Williams and Wilkins; 2013 Aug 29:1585. 
5. Grimwade D, Walker H, Oliver F, Wheatley K, Harrison C, Harrison G, Rees J, Hann I, Stevens R, Burnett A, Goldstone A. The importance of diagnostic cytogenetics on outcome in AML: analysis of 1,612 patients entered into the MRC AML 10 trial. Blood. 1998 Oct 1;92(7):2322-2333.

6. Meng CY, Noor PJ, Ismail A, Ahid MF, Zakaria Z. Cytogenetic profile of de novo acute myeloid leukemia patients in Malaysia. International journal of biomedical science: IJBS. 2013 Mar;9(1):26.

7. Vardiman JW, Thiele J, Arber DA, Brunning RD, Borowitz MJ, Porwit A, Harris NL, Le Beau MM, Hellström-Lindberg E, Tefferi A, Bloomfield CD. The 2008 revision of the World Health Organization (WHO) classification of myeloid neoplasms and acute leukemia: rationale and important changes. Blood. $2009 \mathrm{Jul}$ 30;114(5):937-951.

8. Nakase K, Bradstock K, Sartor M, Gottlieb D, Byth K, Kita K, Shiku H, Kamada N. Geographic heterogeneity of cellular characteristics of acute myeloid leukemia: a comparative study of Australian and Japanese adult cases. Leukemia. 2000 Jan;14(1):163.

9. Mrózek K, Heerema NA, Bloomfield CD. Cytogenetics in acute leukemia. Blood reviews. 2004 Jun 1;18(2):115-136.

10. Löwenberg BB. Diagnosis and prognosis in acute myeloid leukemia-The art of distinction. New England Journal of Medicine. 2008 May 1;358(18):1960-1962.

11. Shipley JL, Butera JN. Acute myelogenous leukemia. Experimental hematology. 2009 Jun 1;37(6): 649-658.

12. Marchesi F, Annibali O, Cerchiara E, Tirindelli MC, Avvisati G. Cytogenetic abnormalities in adult non-promyelocytic acute myeloid leukemia: a concise review. Critical Reviews in Oncology/ Hematology. 2011 Dec 1;80(3):331-346.

13. Enjeti AK, Tien SL, Sivaswaren CR. Cytogenetic abnormalities in de novo acute myeloid leukemia in adults: relation to morphology, age, sex and ethnicity-a single center study from Singapore. The Hematology Journal. 2004 Jan 1;5(5):419-425.

14. Mauritzson N, Johansson B, Albin M, Billström R, Ahlgren T, Mikoczy Z, Nilsson PG, Hagmar L, Mitelman F. A single-center population-based consecutive series of 1500 cytogenetically investigated adult hematological malignancies: karyotypic features in relation to morphology, age and gender. European journal of haematology. 1999 Feb;62(2):95-102.

15. Preiss BS, Kerndrup GB, Schmidt KG, Sørensen AG, Clausen NA, Gadeberg OV, Mourits-Andersen T, Pedersen NT, AML Study Group Region of Southern Denmark. Cytogenetic findings in adult de novo acute myeloid leukaemia. A population- based study of 303/337 patients. British journal of haematology. 2003 Oct;123(2):219-234.

16. Ayesh M, Khassawneh B, Matalkah I, Alawneh K, Jaradat S. Cytogenetic and morphological analysis of de novo acute myeloid leukemia in adults: a single center study in jordan. Balkan Journal of Medical Genetics. 2012 Jan 1;15(1):5-10.

17. Amare PK, Jain H, Kabre S, Deshpande Y, Pawar P, Banavali S, Menon H, Sengar M, Arora B, Khattry N, Narula G. Cytogenetic profile in 7209 Indian patients with de novo acute leukemia: a single centre study from India. J Cancer Ther. 2016 Jun 27; 7:530-544.
18. Peng HL, Zhang GS, Gong FJ, Shen JK, Zhang Y, Xu YX, Zheng WL, Dai CW, Pei MF, Yang JJ. FMS-like tyrosine kinase (FLT) 3 and FLT3 internal tandem duplication in different types of adult leukemia: analysis of 147 patients. Croatian medical journal. 2008 Oct 15;49(5):650-659.

19. Schnittger S, Schoch C, Dugas M, Kern W, Staib P, Wuchter C, Löffler H, Sauerland CM, Serve H, Büchner T, Haferlach T. Analysis of FLT3 length mutations in 1003 patients with acute myeloid leukemia: correlation to cytogenetics, FAB subtype, and prognosis in the AMLCG study and usefulness as a marker for the detection of minimal residual disease. Blood. $2002 \mathrm{Jul}$ 1;100(1):59-66.

20. Haferlach T, Bacher U, Alpermann T, Haferlach C, Kern W, Schnittger S. Amount of bone marrow blasts is strongly correlated to NPM1 and FLT3-ITD mutation rate in AML with normal karyotype. Leukemia research. 2012 Jan 1;36(1):51-58.

21. Tien HF, Wang CH, Lin MT, Lee FY, Liu MC, Chuang SM, Chen YC, Shen MC, Lin KH, Lin DT. Correlation of cytogenetic results with immunophenotype, genotype, clinical features, and ras mutation in acute myeloid leukemia A study of 235 Chinese patients in Taiwan. Cancer genetics and cytogenetics. 1995 Oct 1;84(1):60-68.

22. Johansson B, Mertens F, Mitelman F. Geographic heterogeneity of neoplasia-associated chromosome aberrations. Genes, Chromosomes and Cancer. 1991 Jan;3(1):1-7.

23. Slovak ML, Kopecky KJ, Cassileth PA, Harrington DH, Theil KS, Mohamed A, Paietta E, Willman CL, Head DR, Rowe JM, Forman SJ. Karyotypic analysis predicts outcome of preremission and postremission therapy in adult acute myeloid leukemia: A Southwest Oncology Group/Eastern Cooperative Oncology Group Study. Blood. 2000 Dec 15;96(13):4075-4083.

24. Grimwade D, Walker H, Harrison G, Oliver F, Chatters S, Harrison CJ, Wheatley K, Burnett AK, Goldstone AH. The predictive value of hierarchical cytogenetic classification in older adults with acute myeloid leukemia (AML): analysis of 1065 patients entered into the United Kingdom Medical Research Council AML11 trial. Blood. 2001 Sep 1;98(5):1312-1320.

25. Koczkodaj D, Zmorzyński S, Michalak-Wojnowska M, WąsikSzczepanek E, Filip AA. Examination of the FLT3 and NPM1 mutational status in patients with acute myeloid leukemia from south eastern Poland. Archives of medical science: AMS. 2016 Feb 1;12(1):120.

26. Rezaei N, Arandi N, Valibeigi B, Haghpanah S, Khansalar M, Ramzi M. FMS-like tyrosine kinase 3 (FLT3) and nucleophosmin 1 (NPM1) in Iranian adult acute myeloid leukemia patients with normal karyotypes: mutation status and clinical and laboratory characteristics. Turkish Journal of Hematology. 2017 Dec;34(4):300.

27. Smith ML, Hills RK, Grimwade D. Independent prognostic variables in acute myeloid leukaemia. Blood reviews. 2011 Jan 1;25(1):39-51.

28. Falini B, Mecucci C, Tiacci E, Alcalay M, Rosati R, Pasqualucci L, La Starza R, Diverio D, Colombo E, Santucci A, Bigerna B. Cytoplasmic nucleophosmin in acute myelogenous leukemia with a normal karyotype. New England Journal of Medicine. 2005 Jan 20;352(3):254-266. 